\title{
HEALTH PROMOTION FOR OLDER PEOPLE IN THE CZECH REPUBLIC IN A EUROPEAN PERSPECTIVE
}

\author{
Eva Krížová1, Piotr B rzyski ${ }^{2}$, Charlotte Strumpel ${ }^{3}$, J enny Billingss ${ }^{4}$, Gert Lang ${ }^{5}$ \\ ${ }^{1}$ Charles University in Prague, Third Faculty of Medicine, Prague, Czech Republic \\ 2) agiellonian University Medical College, Krakow, Poland \\ ${ }^{3}$ Austrian Red Cross, Vienna, Austria \\ ${ }^{4}$ Centre for Health Service Studies, University of Kent, UK \\ ${ }^{5}$ Research Institute of the Red Cross, Vienna, Austria
}

\begin{abstract}
SUMMARY
This article describes health promotion for older people in the Czech Republic from the European perspective ${ }^{1}$. It is based on findings from the European project healthPROelderly. Implementation of health promotion in the Czech republic as a new public health concept is outlined from the historical point of view. Structures and processes of health promotion in the Czech Republic are described in the context of social policy, demography and health. The European project healthPROelderly is presented and the outcomes of an international literature search statistically analysed. Participating countries were divided into three macro-regions according to their geographical location and political and historical tradition - Mediterranean, West-E uropean and formerly East-European macro-regions. The outcome of correspondence analysis partially confirms the hypothesis on the cultural background of the health promotion activities and strategies. Concerning themes addressed by health promotion projects most countries belonging to the Mediterranean or "Western European" macro-regions have concentrated on similar themes whereas this is not valid for the countries of the "Former Eastern European" macro-region. The hypothesis on macro-regional similarities in relation to settings of health promotion projects was not confirmed. In the conclusions the location of the Czech Republic in an international perspective is discussed and three Czech selected best practice projects are evaluated in relation to the statistical findings.
\end{abstract}

Key words: health promotion, older people, international comparison, European research healthPRO elderly, social policy, health status, demography

Address for correspondence: E. Křižová, Charles University in Prague, Third Faculty of Medicine, Dept. of Nursing, Ruská 87, 10000 P raha 10, Czech Republic. E-mail: eva.krizova@ If3.cuni.cz

\section{INTRODUCTION}

\section{Health Promotion as a New Agenda of the Czech Public Health in the Early 1990s}

Health promotion as a theoretical concept started to be systematically studied and presented in the Czech Republic in full accordance with the most progressive approaches given by the Ottawa Charter from 1986 only after the political change in 1990. In former Czechoslovakia a well-functioning and effective system of public health control and disease prevention was established during the 20th century. In the 1960s, health education and health information as new approaches addressing the behavioural aspects were added. Health promotion as the historically most recent and hierarchically utmost notion began to emerge only in the late 1980s. Czech health education experts have conveyed their new orientation towards health promotion by renaming the National Institute of Health Education to the National Centre of Health
Promotion ${ }^{2}$ in 1991. This new institute has successfully developed health promotion in theory and formed a platform of experts, who have taken on board new concepts which were developed in the advanced democratic world. By opening the borders, Czech experts were given the chance to attend international meetings, workshops, conferences and had access to literature and training courses like the "Lüneburger" for example, a six weeks training course organised by the Lüneburg Fachhochschule ${ }^{3}$ under the auspices of the WHO. As a result, health promotion as a theoretical concept has now been set apart from the rather traditional concepts of prevention and health education. A consensus about the specific contribution that health promotion can bring has been reached through a thorough debate, at least among those people engaged in the subject. As a consequence of this theoretical discourse, numerous health promotion projects using the social settings approach and networking have successfully been implemented, the most relevant among them were Healthy School and Healthy

${ }^{1}$ Partners of the healthPROelderly project will be included in the comparison (Poland, Germany, United Kingdom, Austria, The Netherlands, Spain, Greece, Slovenia, Slovakia, Italy and the Czech Republic)

${ }^{2}$ Both were state institutions financed and administered by the Czech Government, Ministry of Health.

${ }^{3}$ The approx. 16 training courses were organised by Lotte Kaba Schonstein from Lüneburger Fachhochschule. 
City networks, and to a lesser extent, Healthy Workplace projects. Healthy Family and Healthy Hospital projects were not so successful, even though recently approved by the National Programme on Health - Health Promotion Projects. The explanation for this might be that since the Czech Republic is a post-totalitarian society, people might fear public intervention into their private sphere. In the case of hospitals people might be wary that these are closed systems and are basically disease-oriented. Unfortunately, the political situation in the early 90s was significantly affected by neo-conservative values and this led to a politically motivated dissolution of the National Centre of Health Promotion in 1995. Part of its agenda was transferred to the National Institute of Public Health, but other parts were completely withdrawn. The Bulletin of the National Centre of Health Promotion as the only country's periodical on health promotion has also disappeared. Although this research institute was dissolved, health promotion remained on the political agenda and the National Programme on Health Promotion was approved in 1993. However, the missing structures in health promotion and the lack of a periodical in these fields have probably led to insufficient theoretical reflection (1). The consequence was that under the new slogans of health promotion traditional disease prevention and health education projects have tended to prevail.

In 1994 the state programme "Health Promotion Projects" was launched. A major goal of this programme was to subsidise intervention projects dealing with older population groups. The National Programme on Health - Health Promotion Projects is still in force under the care of the Czech Ministry of Health, however only 24 projects were approved for the year 2008, two of them addressing older people. A grant scheme addressing seniors was available only on a temporary basis (between 2004-2007). In 2004 a state grant programme "Healthy Ageing Projects" "was launched focusing on people over 55 years old, but in 2007 it was reorganised once again and the age-specific agenda was abandoned. Since 2008 health promotion projects for seniors can be submitted again within the unified health promotion scheme. Both grant schemes were administered by The Ministry of Health or its designated organisations (National Institute of Public Health) and financed by the state. In 2004, WHO experts recommended to increase the political priority and legitimacy of health promotion and advised to examine the current system of financing and fund-raising in health promotion (2).

\section{Demographic, Social and Health Status of Seniors in the Czech Republic}

In the Czech Republic - as is the case in other European countries - ageing is rapidly increasing due to a gain in life expectancy and an extremely low birth rate since 1990's '. In 2007 $14.5 \%$ of inhabitants were aged $65+$ (more than 1,5 mil.), while in 2030 this is expected to reach $22.8 \%$, and in $205031.3 \%$. The
Table 1. Percentage of population $65+$ in partner countries in 2007

\begin{tabular}{|l|c|}
\hline $\begin{array}{l}\text { Source: UNECE-United Nations Economic Commis- } \\
\text { sion for Europe }\end{array}$ & Pop. 65+ in \% \\
\hline Germany & 20.1 \\
\hline Italy & 20.0 \\
\hline Greece & 18.6 \\
\hline Austria & 17.2 \\
\hline Spain & 16.6 \\
\hline United Kingdom & 16.2 \\
\hline Slovenia & 16.0 \\
\hline The Netherlands & 14.6 \\
\hline Czech Republic & 14.5 \\
\hline Poland & 13.4 \\
\hline Slovakia & 11.9 \\
\hline
\end{tabular}

proportion of persons in the highest age range $(85+)$ is growing most rapidly and the life expectancy in both sexes is expected to carry on increasing (up to 84 years in males and 88 years in females estimated by 2065). The relative amount of seniors will increase in coming decades due to the ageing of the early 1970's "population boom” age cohort which was the consequence of large pro-natality measures in social policy during the so called political "normalization" period. The age structure in the CR measured by the age preference index is so far aligned to the EU average, but if present trends persist the population of the CR may gradually become one of the oldest in Europe (Table 1) (3).

Between 1990 to 2005, positive changes in life expectancy of both males and females occurred in the CR which have somewhat reduced the lag behind the EU countries ${ }^{6}$. Among countries of Central and Eastern Europe the Czech Republic ranks second, behind Slovenia in life expectancy (Table 2). The main causes of mortality in the long-term perspective are the following: diseases of the circulatory system (47\% in males, $52 \%$ in females), cancer (28\% in males, $27 \%$ in females) with a high proportion of breast cancer in females, cancer of the colon in males, and external injuries and poisonings (7.6\% in males, $4.2 \%$ in females). The contribution of behavioural and environmental components to the proportion of the so-called "civilization" diseases is relatively high. Only $25.0 \%$ of males at the age of $65-74$ years and $8.3 \%$ of females of the same age do not report any chronic disease (4). Among the civilization diseases, hypertension, arthritis, musculoskeletal disorders, chronic headache and allergies frequently lead to a high prevalence of chronic pain and negatively influence the quality of life. Next to pain, recurrent complaints of seniors encompass sleep disorders, dyspnoea, giddiness (vertigo) and fatigue

\footnotetext{
${ }^{4}$ Through this programme, health promoting activities of NGO's, charity organisations and municipalities/communities were implemented. Only projects of 1-year duration were eligible. Those projects include relaxation stays for seniors, weekly courses and trainings, lectures and education, editorial and information activities, counselling, networking and rental of health aids and appliances. Since 2005 the annual prize called Makropulos has been awarded in order to praise the best-practice health promoting project for seniors.

${ }^{5}$ The fertility rate is slightly rising from its lowest point of 1,13 in 1999 to 1,44 in 2007.

${ }^{6}$ Life expectancy in both sexes was below the EU 15 average before the EU extension.
} 
Table 2. Life expectancy (LE) in males and females in partner countries in 2006

\begin{tabular}{|l|c|c|}
\hline $\begin{array}{l}\text { Source:UNECE-United Nations } \\
\text { Economic Commission for Europe }\end{array}$ & $\begin{array}{c}\text { LE } \\
\text { in males }\end{array}$ & $\begin{array}{c}\text { LE } \\
\text { in females }\end{array}$ \\
\hline Italy (2004) & 77.9 & 83.8 \\
\hline Greece & 77.2 & 81.9 \\
\hline Spain & 77.7 & 84.4 \\
\hline United Kingdom & 77.4 & 81.8 \\
\hline Austria & 77.2 & 82.8 \\
\hline Germany & 77.2 & 82.4 \\
\hline Slovenia & 74.5 & 82.0 \\
\hline The Netherlands & 77.8 & 82.1 \\
\hline Czech Republic & 73.5 & 79.9 \\
\hline Poland & 71.0 & 79.8 \\
\hline Slovakia & 70.4 & 78.4 \\
\hline
\end{tabular}

(5). Similarly, many negative health consequences result from a high incidence and prevalence of diabetes type 2 . However, some positive trends can be found due to the stabilisation of chronic disease and potential decrease of mortality due to malignant neoplasms, and will be likely to continue in the near future.

The proportion of obese and overweight people is considerable, $21 \%$ of males and $29 \%$ of females in the age group of $65-74$ years old have a BMI greater than 30 . The highest proportion of obese people is in the 55-64 age group (6). These trends are however changing for the better, as the most recent surveys indicate that the dietary index is slightly improving and it is notably improving in the oldest groups (7). Even though cardiovascular mortality has remarkably decreased since 1990, due in part to technological modernisation of cardiosurgery care and positive changes in the lifestyle (decrease in consumption of meat and animal fat, increase of consumption of fruits and vegetables), the burden of chronic diseases results in the high use of medical services and drugs, coupled with a low subjective satisfaction with personal health. Nevertheless, even in this respect a positive shift has recently been detected.

Every older citizen in the Czech retirement system is entitled to retirement benefits and can be assured of the minimum pension. The retirement age is different for men and women and currently spans from 55 to 62 years, increasing to 59-63 years in females (depending on numbers of children) and 63 years in men by 2020 . The reform of the pension system is currently being politically debated and is considered an urgent issue. Equal access to comprehensive health care through the mandatory public health insurance is guaranteed to every citizen. The coverage is large, but new co-payments have been in force since January 2008. Health insurance of pensioners is financed from the state budget. Traditionally, provision of health and social care was concentrated in institutions (hospitals, older people's homes, residential nursing homes etc.). Extramural care (e.g. home care) has only been implemented recently. Though this is slow to progress, the po- litical support of independent living and family care has become apparent. However, rising financial tensions in the health care budget and persisting ideological and organisational stereotypes and traditions (giving priority to large professional health and social care institutions instead of small independent outpatient providers or lay care) are partly responsible for why there is a gap between the implementation of reforms and the practical needs of the population. Older people are likely to differ substantially with respect to their health, mental state as well as their social and/or economic situation. These inequalities have not been systematically studied, despite the rhetoric of equity. However, regional differences do provide some clues to variations in life expectancy; differences in mortality, and accessibility to health care, which have been monitored and noted by the national health statistical system.

\section{Policy Initiatives for Older People and Health Pro- motion}

With its EU-membership, the Czech Republic has also begun to implement aspects of health and social policy as advocated by the European Commission and other international organisations. The WHO programme "Health for all - Agenda 21" was adopted as a basic document for national health policy. The country has been actively participating in the Healthy Ageing project funded by the Public Health Programme of the European Commission and consequently, national projects were developed like e.g. the ActiveAge project. During the Social Democratic government (1998-2006), the National Programme of Preparation for Ageing for the period 2003-2007 was passed in 2002. Ageing is being perceived as a problem concerning the entire society, not only of older people themselves. The underlying values are respect for human rights, solidarity, self-determination and dignity. Preparation for ageing is considered to be a life-long process which apart from the social and collective responsibility embraces also the individual contribution of each person. The Ministry of Labour and Social Affairs has prepared the Social Services Act which has profoundly changed the provision of social services enhancing the competence of the beneficiaries since 2007. A person with a disability is eligible for a financial allowance which enables him or her to decide what services he or she will purchase in the end ${ }^{7}$. In 2004 the National Action Plan for Social Inclusion for the period of 2004-2006 was adopted by the government in order to prevent people, including seniors from poverty and social exclusion. The Plan continued in the period 2006-2008 and has been prolonged for the period 2008-2010. In 2006 the Czech Republic became a partner in an European project "From isolation to inclusion: Promoting innovation in re-integrating older citizens into community life”. During 2004-2005 the National Programme on Computer Literacy has been in process focusing especially on the higher age groups. Many steps were undertaken in order to eliminate the physical barriers in access to public buildings and transport means. The Government Council for Older Persons and Population Ageing was installed in 2006 at the Ministry of Labour and Social Affairs. The council consists of representatives of the government, NGOs, health insurance companies and other social 
partners. Its four working groups concentrate on the following priorities: 1. support of employment, lifelong learning and social security, 2. improvement of health and social services for seniors, 3. awareness raising and anti-discrimination, 4. housing and residential social services. At the regional level, councils of seniors were established as advisory bodies to some regional authorities. Further, large research projects on mapping the situation of older people in the CR have started. The continuation of the National Programme of Preparation for Ageing for the period 2008-2012 explicitly points out next priorities: active ageing, age-friendly community, improvement of health and health care for elderly, support of caring families, support of social participation of the elderly and protection of their human rights. Even though age discrimination (at least as concerns employment) is forbidden by law (Labour Code 262/2006 Coll.), various signs of negative attitudes towards older people have not been fully eliminated yet (8), and are likely to be the by-product of the complex social change in 1989 which has favoured mostly young and healthy persons over others. Especially the disadvantaged situation of older workers in the labour market and a desirable diversification of geriatric care within the community in the near future demand our further attention, official documents and experts say (9). Positively, NGOs play important role in making voices and views of older people heard (10).

\section{MATERIAL AND METHOD}

\section{International Comparison of the Literature Search and Multidimensional Analysis}

Thanks to the initiative of the Austrian Red Cross the European project healthPROelderly (www.healthproelderly.com) was launched in 2006 lasting 30 months (4/2006-9/2008 $)$. The aim of the project was to map the situation of health promotion for older people in 11 European countries (Austria, the Czech Republic, Greece, Italy, Germany, the Netherlands, Poland, Slovenia, Slovakia, Spain, United Kingdom). The main focus of the healthPROelderly project was to identify criteria which make health promotion programmes for older people successful and to provide evidence for these programmes' sustainable effects. In the initial phase, each country collected literature findings that were statistically processed. 1,788 items of literature were gathered by 11 participating countries $(11)^{9}$. The final step of the statistical overview over all participating countries was to depict similari-
Table 3. Themes and topics

\begin{tabular}{|l|l|}
\hline Health determinants & \\
\hline Quality of life & $\begin{array}{l}\text { Addressing depression, stress/burn out, } \\
\text { cognitive issues, e.g. memory training, } \\
\text { self-respect/dignity, emotional support }\end{array}$ \\
\hline Promoting mental health & $\begin{array}{l}\text { Life-long learning, education of older } \\
\text { people, social support/networks, self- } \\
\text { help groups, volonteering }\end{array}$ \\
\hline Empowerment & $\begin{array}{l}\text { Nutrition, physical activity, sexual } \\
\text { activity, substance abuse (smoking, } \\
\text { alcohol, drugs), safety (e.g. prevention } \\
\text { of falls, accidents, injuries), preventing } \\
\text { abuse/violence against older people, } \\
\text { prevention of disease }\end{array}$ \\
\hline Life style
\end{tabular}

ties and differences between countri es in relation to each other and in relation to selected variables ${ }^{10}$. In this phase the analysis concentrated on "themes" and "settings" of health promotion projects. Literature items were studied in order to identify the key themes and topics: health determinants, quality of life, promoting mental health, empowerment, social participation/inclusion and/or lifestyle. Literature items could be associated with more themes than just one. Several themes and topics like promoting mental health, social participation/inclusion, and life style were subcategorised (Table 3). The variable "themes" was dichotomic for each of the sub-categories (yes, no). The variable "settings" inquired which social settings were addressed by the project. The following settings were suggested - workplace, residential homes for the elderly, community (e.g. city, region), neighbourhood, school, people's own homes. Projects could address more than one setting. The variable was also dichotomic (yes, no).

Countries involved in the project are very diverse owing to their historical, cultural and geographical roots, however three geographical and cultural patterns (macro-regions) are suggested and consequently, certain similarities in approach to health promotion themes are expected ${ }^{11}$.

- a Mediterranean macro-region (represented by Greece, Italy and Spain);

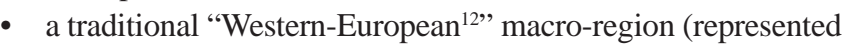
by the Netherlands, Germany, United Kingdom, and Austria);

\footnotetext{
${ }^{8}$ Financed by the Public Health Programme of the DG Sanco of the European Commission.

${ }^{9}$ The description of the outcomes can be found in detail in the "Overview on health promotion for older people- European report", ed. Charlotte Strümpel and Jenny Billings (http://www.healthproelderly.com/pdf/hpe_European_Report_May_2008.pdf).

${ }^{10}$ Based on the original project proposal and owing to the rich group discussion on methodological procedures we decided to employ correspondence analysis. It is a descriptive and exploratory technique which graphically illustrates the underlying relationships between categories and variables, i. e. in this paper between countries and themes or settings. Correspondence analysis transforms the frequencies in cells of two-way or multi-way tables into measures of distance which enables presenting the relationships between variables as distances between the categories of variables in two-dimensional space.

${ }^{11}$ However, it is necessary to stress, that healthPROelderly was not a scientific project which primarily aimed at testing cultural differences in health promotion approach. The data gained in the international literature search served purposely to generate inclusion and exclusion criteria for identification of good and best examples of health promotion for older people.

${ }^{12}$ We use quotation marks in labelling the Western and Eastern European macro-regions because those terms express rather the political affiliation than strictly geographical.
} 


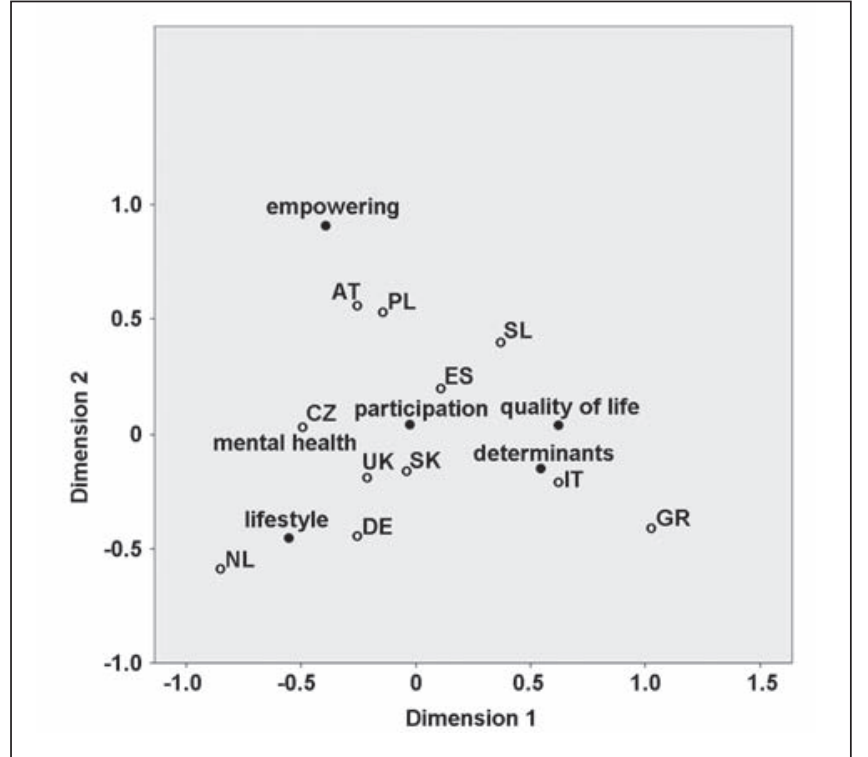

Fig. 1. Themes addressed by countries.

- and a "Formerly Eastern European" macro-region (represented by Poland, the Czech Republic, the Slovak Republic and Slovenia).

\section{RESULTS}

Results of correspondence analysis (Fig. 1) show a different choice of themes in different European countries. Those which addressed many themes simultaneously are located in the centre of graph (UK, Spain, Slovakia, participation as the central category), whereas those focusing rather on particular themes are located rather in the periphery. The latter group includes Italy and Greece (i.e., mainly addressing health determinants), the Netherlands and Germany (i.e., lifestyle), the Czech Republic (i.e., addressing mental health) and Austria and Poland (i.e., addressing empowerment). Countries most closely related to each other in terms of themes covered include Germany, United Kingdom, and Slovakia, which addressed lifestyle, mental health, and participation to a similar extent. Slovenia seems to stay as an outlier without any tight reference to a concrete theme.

Concerning our expectations we find Italy and Greece close to each other, whereas in another quadrant we can locate United Kingdom, Germany and the Netherlands. With the exception of Spain and Austria most countries in the Mediterranean macroregion as well as in the "West-European" macro-region are close to each other. Reversely, countries which have been identified as “former Eastern European Countries” demonstrate a high degree of diversity.

In a further step, we examined similarities and differences between countries by means of correspondence analysis concerning the settings that the health promotion projects or actions for older people took place in (Fig. 2). Germany and especially Austria more frequently address the workplace, while the Czech projects concentrate prevailingly on people's own homes and residential

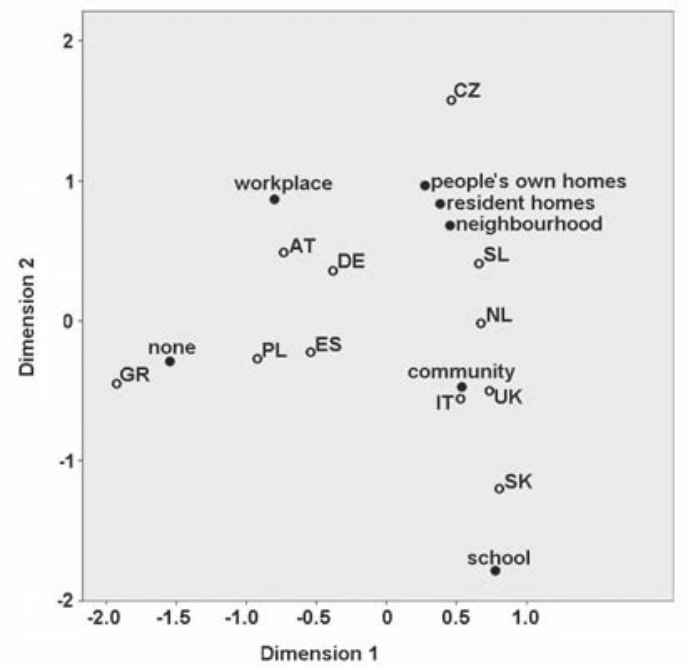

Fig. 2. Settings addressed by countries.

homes. In Slovenia, the neighbourhood is more likely as a setting, whereas in Italy and UK community was the place of health promotion activities to a higher degree. Slovakia also reported community as a setting and has found more projects in school settings than most other countries. In Greece and Poland relatively many projects did not indicate any of the suggested settings. To a certain degree this also can be said for Greece, however its central position means that Greece also reported projects addressing both community, workplace and neighbourhood.

It can be concluded that the correspondence analysis has produced findings which allow us to say that there are emerging patterns of similarities between Mediterranean and Western European countries in themes selection whereas this cannot be stated for the group of Former Eastern European countries. From the view of settings which have been addressed by the literature items no patterns as suggested before (Mediterranean, Western European and Former Eastern European) have appeared.

\section{DISCUSSION}

\section{How Can we Read the Position of the Czech Republic in the International Comparison?}

As it has been described above, health promotion as a notion and activity is in theory well distinguished from prevention of disease and health education in the Czech Republic. Health promotion as a new agenda has been explicitly articulated after 1989 and has been based on the well-established tradition of health education and disease prevention. The Czech literature items in the final literature collection were generated from 1. existing databases of health promotion projects subsidised by the grant programme "Health Promotion Projects" of the Ministry of Health and administered by the National Institute of Public Health and 2. from the database of Healthy Ageing Programme, administered by 
Table 4. Themes - comparison of the CR and the total sample (the figures represent positive answers)

\begin{tabular}{|l|c|c|}
\hline & $\begin{array}{c}\text { Czech Republic } \\
\text { (N=109) }\end{array}$ & $\begin{array}{c}\text { The total sample } \\
\text { (1788) }\end{array}$ \\
\hline Health determinants & 39.4 & 49.6 \\
\hline Quality of life & 51.4 & 56.7 \\
\hline Promoting mental health & 55.9 & 31.7 \\
\hline Empowerment & 42.2 & 35.4 \\
\hline Social participation & 57.8 & 42.0 \\
\hline Lifestyle entirely & 85.3 & 56.7 \\
\hline Nutrition within lifestyle & 19.3 & 7.9 \\
\hline Physical activity within lifestyle & 19.3 & 10.6 \\
\hline
\end{tabular}

the Czech Ministry of Health between 2004-2007. It proves that health promotion terminology is used as an overarching concept embracing disease prevention, health education and broader issues. In practice however, the contents and strategies are very often considered as hardly separable. Comparatively, Czech projects focused mostly on lifestyle, promoting mental health, social participation and quality of life (85.3\%, 55.9\%, 57.8\% and 51.4\% of the items ${ }^{13}$ ). The frequency of lifestyle themes was remarkably higher in the CR compared to the European context whereas the prevalence of quality of life items was fairly similar (Table 4). The dominance of the lifestyle category in the CR was also apparent in the subthemes of nutrition and physical exercises. In $42 \%$ of the items empowerment was identified as the main theme. The scope of themes which were addressed by Czech health promotion projects was similarly wide, nevertheless a special emphasis was paid to traditional prevention and health education issues like lifestyle (especially to nutrition and physical activity) and mental health. Mostly the examined projects took place in people's own homes (34.9\% of items) or residential homes (25.7\% of items), whereas schools, the workplace or the neighbourhood were identified only rarely. Also, community represented by city or region was reported much less in the Czech Republic compared to other countries (Table 5). Noticeably, some health promotion projects for older people have been organised by hospitals.

In the project phase following the literature search each country identified three best practice projects according to the list of inclusion and exclusion criteria and their scoring which was developed within the project (Table 6, detailed description on www.healthproelderly.com). For the Czech Republic, following projects represented the country: "Delicious Life" , a project aiming at the improvement of nutrition in older people by a series of cooking and tasting sessions, "Dance Therapy" a project which introduced dancing elements in a group of older people, among them many suffering from dementia, and "Reminiscence Therapy”, a project which improved the self-esteem and social recognition on the basis of organized group reminiscing (detailed description of the projects can be found in the National Evaluation Report-Czech Republic, ref. 10). Whereas the first project addressed nutrition prevailingly and as a second theme physical exercise and social participation, "Dance Therapy" and
Table 5. Settings - comparison of the CR and the total sample

\begin{tabular}{|l|c|c|}
\hline Settings & $\begin{array}{c}\text { Czech Republic } \\
\text { (N=109) }\end{array}$ & $\begin{array}{c}\text { The total sample } \\
\text { (1788) }\end{array}$ \\
\hline Workplace & 2.8 & 3.1 \\
\hline Residential homes & 25.7 & 8.1 \\
\hline Community (city, region) & 10.1 & 31.1 \\
\hline Neighbourhood & 0.0 & 1.1 \\
\hline School & 0.0 & 0.7 \\
\hline People's own homes & 34.9 & 10.0 \\
\hline Other settings (e.g. hospital) & 6.4 & 10.3 \\
\hline
\end{tabular}

Table 6. Selected best projects in the CR

\begin{tabular}{|l|l|l|}
\hline $\begin{array}{l}\text { Project title and coor- } \\
\text { dinator }\end{array}$ & Main themes & Setting \\
\hline $\begin{array}{l}\text { Delicious Life (Lumír } \\
\text { Komárek) }\end{array}$ & $\begin{array}{l}\text { nutrition, physical } \\
\text { movement, social } \\
\text { participation }\end{array}$ & social care institutions \\
\hline $\begin{array}{l}\text { Effect of dance therapy } \\
\text { on health status and } \\
\text { quality of life of residents } \\
\text { in care homes (Petr } \\
\text { Veleta) }\end{array}$ & $\begin{array}{l}\text { physical movement, } \\
\text { mental health, quality } \\
\text { of life }\end{array}$ & residential homes \\
\hline $\begin{array}{l}\text { Effect of reminiscence } \\
\text { therapy on the health sta- } \\
\text { tus and quality of life of } \\
\text { residents of care homes } \\
\text { (Hana J anečková) }\end{array}$ & $\begin{array}{l}\text { social participation, } \\
\text { quality of life, mental } \\
\text { health }\end{array}$ & residential homes \\
\hline
\end{tabular}

“Reminiscence Therapy” deliberately focused on promoting mental health, quality of life and social participation via physical elements (dancing) and communication (talking, narrating). Each of the projects took place in a residential home for older people. Taking into account the statistical outcomes we may conclude that the selection of the best health promotion projects for older people according to explicit inclusion and exclusion criteria fits well with the literature findings both concerning themes and settings. Even though there are remarkable achievements in the field of health promotion in the Czech Republic, we have to admit that health promotion has still not been given the political priority as it deserves. The priority of residential homes and people's own homes as the main project settings and the dominance of lifestyle issues indicate the still rather traditional approach to health promotion which stresses the individual over the community and private areas (people's homes, residential homes) to public space (like city, region, school, workplace).However, increasingly Central and Eastern European countries are becoming aware of the need for change in line with European and WHO policy (14-19).

\footnotetext{
${ }^{13} 109$ literature items have been collected, representing $6,1 \%$ of the total research sample $(\mathrm{N}=1788)$.
} 


\section{Acknowledgements}

This article is based on research outcomes gained within the European project healthPROelderly, which was financed within the DG Sanco Public Health Programme. We would like to thank to all members of participating teams who have contributed to the literature database and other projects phases.

\section{REFERENCES}

1. Evaluation of health promotion policy and its infrastructures in the Czech Republic. Prague: MZČR, IZPE; 2004. p. 17. (In Czech.)

2. Evaluation of health promotion policy and its infrastructures in the Czech Republic. Prague: MZČR, IZPE; 2004. p. 38. (In Czech.)

3. UNECE statistical database [Internet]. Geneva: UNECE-United Nations Economic Commission for Europe [cited 2009 Mar 10]. Available from: http://w3.unece.org/pxweb/Dialog/Saveshow.asp.

4. Chronic morbidity. In: HIS CR 2002: sample survey of the health status of the Czech population. Prague: ÚZIS ČR; 2004. p. 40.

5. Zavázalová H. Selected chapters for social gerontology. Prague: Karolinum; 2001. (In Czech.)

6. Height, weight and Body Mass Index (BMI). In: HIS CR 2002: sample survey of the health status of the Czech population. Prague: ÚZIS ČR; 2004. p. 22.

7. Daňková Š, Chudobová M, Kamberská Z, Popovič I, Tvrdá J. Comparison of selected health indicators in EU and CR [Internet]. Prague: ÚZIS ČR; 2004 [cited 2006 Dec 20]. Available from: http://www.uzis.cz/download. php?ctg=10\&search_name=EU\%20a\%20 ČR\&region=100\&kind=2\&m nu_id=5300.

8. Vidovicová L, Rabušic L. Age discrimination - ageism: an introduction to the theory and incidence of discrimination approaches in selected areas with emphasis on labour market. Prague: VÚPSV; 2005. (In Czech.)

9. Kalvach Z. The expetations and disappointment of medicine - a gerontological aspect. In: Mášová H, Křížová E, Svobodný P, editors. Czech healthcare - vision and reality. Prague: Karolinum; 2004. p. 165-87. (In Czech.)

10. Wija P. Report on the quick scan of policy and research documents on empowerment and participation of older citizens in the Czech Republic
[Internet]. Prague: Ministry of Labour and Social Affairs; 2006 [cited 2009 Jul 2]. Available from: http://www.i2i-project.net/pdfs/QuickScan_CzechRepublic.pdf.

11. Strümpel Ch, Billings J, editors. Overview on health promotion for older people: European report. Vienna: Austrian Red Cross; 2008.

12. EuroHealthNet [Internet]. Brussels: EuroHealthNet [cited 2008 Jan 14]. Available from: http://www.eurohealthnet.eu/images/publications/ pu_3.pdfwww.eurohealthnet.org.

13. Kř́̌žová E. National evaluation report - Czech Republic [Internet]. Prague: Third Faculty of Medicine,Charles University; 2008 [cited 2009 Mar 10]. Available from: http://www.healthproelderly.com/pdf/National_Evaluation_Report_Czech_Rep_fina.pdf.

14. Report on the implementation of the UNECE Regional Implementation Strategy (RIS) for the Madrid International Action Plan on Ageing in the Czech Republic [Internet]. Prague: Ministry of Labour and Social Affairs of the Czech Republic; 2007 [cited 2009 Mar 10]. Available from: http:// www.mpsv.cz/files/clanky/4541/Report_RIS_CzechRepublic.pdf.

15. Lezovic M, Raucinová M, Kovác A, Moricová S, Kovác R. Long-term care in developed countries and recommendations for Slovak Republic. Cent Eur J Public Health. 2008 Mar;16(1):21-5.

16. Bencko V, Hnilicová H, Klein O. Quality of life, sustainable future and medical education. Cent Eur J Public Health. 2005 Sep;13(3):112-6.

17. Gulis G, Garrido-Herrero L, Katreniakova Z, Harvey G, McCarthy M; Slovak Public Health Association. Public health research priorities in Europe seen by non-governmental organizations. Cent Eur J Public Health. 2008 Dec;16(4):209-12.

18. World Health Organization launches new initiative to address the health needs of a rapidly ageing population. Cent Eur J Public Health. 2004 Dec;12(4):210, 216.

19. Community Action in the Field of Public Health 2003-2008. Determine- European Consortium in Socio-Economic Determinants of Health [Internet]. Brussels: European Commission, DG SANCO; 2002 [cited 2009 Mar 10]. Available from: http://ec.europa.eu/health/ph_programme/ howtoapply/proposal_docs/workplan2005_en.pdf.

Received December 31, 2008 Accepted in revised form April 8, 2009 